\title{
An Assessment on Plagiarism Policies of Journals
}

\section{Akademik Dergilerin İntihal Politikalari Üzerine Bir Değerlendirme}

\author{
Yasemin Akgül ${ }^{1}$ (D), Merve Dikicioğlu ${ }^{1}$ (D), Sheikh Nazmul Huda ${ }^{1}$ (D) \\ ${ }^{1}$ Graduate Student,1Department of Accounting, School of Business, Istanbul University, Istanbul, Turkey \\ ORCID: Y.A. 0000-0002-3555-4068; M.D. 0000-0002-3629-9978; S.N.H. 0000-0001-9580-1756
}

\begin{abstract}
Plagiarism is a very important and debated topic in this modern technological world, however, this issue has been explored by very few people. In every developed or developing country, the crime of plagiarism is committed. Of course, the proportion and intensity of this is higher in developing countries than in developed countries. Plagiarism occurs in many countries in different areas and types. Plagiarism can be of many kinds, but in short it is an unethical way of showing the works belonging to others as if they were his own. In Turkey, as in all the world, the number of master's and doctoral graduates has increased in the last decade. When plagiarism is mentioned, people mostly think about plagiarism done by students, but academicians or authors are always ignored. In this study, we will examine the plagiarism policies of journals to which articles are submitted by academics and authors, and the importance that journals give to this subject. Every single journal has its own rules and regulations regarding its plagiarism policy, but the question is, are those policies enough to prevent plagiarism? If so, do they really implement their policies while publishing an article?
\end{abstract}

Keywords: Plagiarism, Plagiarism Policies, Turkey

öz

Bu modern teknolojik çağda intihal çok önemli ve tartışmalı bir konudur ancak acı gerçek şu ki bu konu çok az kişi tarafından incelenmiştir. Gelişmiş veya gelişmekte olan her ülkede, intihal suçu işlenmektedir. Elbette, bunun oranı ve yoğunluğu gelişmekte olan ülkelerde, gelişmiş ülkelere göre daha yüksektir. İntihal, birçok ülkede farklı alanlarda ve türlerde ortaya çıkar. İntihal birçok şekilde olabilir ancak kısaca başkalarına ait olan eserleri kendininmiş gibi göstererek etik olmayan bir davranış içerisinde olmaktır. Tüm dünyada olduğu gibi Türkiye'de de, son on yılda Yüksek Lisans ve Doktora mezunlarının sayısı artmıştır. İntihal söz edildiğinde, insanlar çoğunlukla öğrenciler tarafından yapılan intihal hakkında düşünür, ancak akademisyenler veya yazarlar her zaman göz ardı edilir.

Bu çalışmada, akademisyenler ve yazarlar tarafından makale gönderilen dergilerin intihal politikalarını ve dergilerin bu konuya verdiği önemi inceleyeceğiz. Her derginin intihal politikasına ilişkin kendi kuralları ve düzenlemeleri vardır, ancak asıl soru, intihal önlemeye yönelik politikalar yeterli midir? Eğer öyleyse, bir makale yayınlarken politikalarını gerçekten uyguluyorlar mı?

Anahtar kelimeler: İntihal, İntihal Politikaları, Türkiye

\section{Introduction}

Every scientific study and research is a continuation of each other and it is necessary to examine the previous ones and make a wide literature review to do unique and comprehensive studies (Uçak and Birinci, 2008, 188). Some publication and ethical rules must be observed when conducting these researches and making use of previous studies. If these rules are not followed, a crime called plagiarism arises. Plagiarism is the deliberate process of copying and stealing others' ideas and words without any citation or with inadequate citation, and it is an unethical act usually done intentionally (Shashok, 2011, 303).

Submitted/Başvuru: 06.07.2019 Accepted/Kabul: 16.07.2019

Corresponding author/Sorumlu yazar: Merve Dikicioğlu / dikicioglumerve66@gmail.com

Citation/Atıf: Akgul, Y., Dikicioglu, M., Huda, S. N. (2019). An assessment on plagiarism policies of journals. Muhasebe Enstitüsü Dergisi - Journal of Accounting Institute, 61, 93-102. https://doi.org/10.26650/MED.2019587928 
There are many resources written about plagiarism done by students, but there are very limited studies on plagiarism done by academicians and researchers. In such an event, the authors' writings are retracted from the magazine and a letter of apology is expected from the authors. Some journals ban these authors for a certain period of publication. Thanks to plagiarism programs such as "Turnitin" and "iThenticate", which emerged along with technological developments, it became possible to obtain a numerical value for the specificity of the works. The level accepted around the world is $15 \%$, but there are areas that accept lower levels (Toprak, 2017, 4).

Plagiarism has been moved to a different dimension with the increase of accessible information over the internet. The judgment that the information on the Internet is public domain is another important element that increases plagiarism (Uçak and Birinci, 2008, 194). Although plagiarism is known as a behavior that should not be done, the importance of the subject is not known, and exactly what needs to be done, causing errors to continue. It is also important that the ethical perception of schools or journals is not fully established. Especially in Turkey, there are shortcomings and disregard toward ethical rules and plagiarism in the academic and scientific journals.

In Turkey, the monitoring and oversight of broadcasting ethics are largely under authority of the Higher Education Council, TUBITAK and university ethics committees. Some measures are taken to prevent plagiarism in the world. For example, a Committee of Science and Ethics was established in China, Pakistan cuts funds to universities that do not punish academics who are responsible for plagiarism and in Turkey, the Research and Publication Ethics Board has been established under TÜBİTAK (Uçak and Birinci, 2008, 196). Many groups have a responsibility to prevent plagiarism such as the author's responsibility, responsibility of the research institution, editor's responsibility, referee and consultant responsibility and the responsibility of the reader (Uçak, 7-8). In addition, some studies show that in developing countries, plagiarism crimes happen more than in developed countries.

This study aims to determine the importance of plagiarism and applied policies for plagiarism in the journals in Turkey. In addition, within the scope of this study, if there is a crime of plagiarism, we will try to find out how the process has been handled and resulted. We will try to come to a conclusion on whether the measures are working, and whether measures and punishments are adequate or not. We will also try to reach clearer results by comparing it with other countries in terms of plagiarism policies and penalties. Thus, we can see whether there are sufficient plagiarism policies in Turkey on the international scale.

\section{Literature Review}

There are various studies on academic dishonesty and the majority of papers focus on plagiarism of students and universities' policies regarding the issue. On the other hand, there is scarcity in the number of research conducted and written on plagiarism policies of academic journals. According to Solmaz Karabağ and Christian Berggren who mentioned in their article that it is new that plagiarism has become a big issue in academic journals. However, there is a lot of pressure that makes even prestigious journals retract papers of prominent researchers and forces them to announce plagiarism policies in their websites (Karadağ and Berggren, 2012, 172-183).

Also, the researchers examine four well-known databases which are EBSCO Business Source Premier, Emerald, JSTOR and ScienceDirect to find the occurrence and reactions against plagiarism in academic journals. Science Direct reveals that "700 papers were retracted from scientific journals, mostly from medical journals between December 1985 and November 2012" (175), Research Policy retracted two papers, EBSCO Business Source Premier retracted 20 papers in management and business journals and JSTOR retracted one paper in 2017, in spite of having more than 170 academic journals. Based on these results, authors question whether economic and business journals are highly academically honest or they have more effective policies than scientific journals. Then, they searched plagiarism policies of these academic journals in those databases. They find that Academy of Management Journal in EBSCO, Research Policy in ScienceDirect, Journal of Applied Economics and Business Research in Econlit published their originality policies, but they could not find it for the others. Additionally, the researchers could not find actions taken against the retracted papers of authors. 
Due to its importance, there is a tendency to establish regulations against plagiarism. Strict regulations exist in Denmark and the United States. However, Australia, Canada, China, Finland, Germany, India, Norway, Poland and Sweden have formal governmental procedures for academic dishonesty (Laskar, 2017, 3). Besides, in the paper, it is recommended to editors of journals that they should verify data requesting data file from researchers when they use data, and editors can make a query to other authors in the department. It is also recommended that if they find severe research misconduct, they can ban those authors or put them on a blacklist to examine their future work with extra effort. Nonetheless, if the paper has new ideas and is worth publishing although it has severe plagiarism, the author can be encouraged to rewrite. Moreover, it is pointed out that in the case of multiple authors work, each author is responsible for misconduct; therefore, they should be informed by reading journal's guide. In short, this paper gives advice to editors about dealing with research misconduct.

According to the research conducted by Enders and Hoover, they alluded that penalties play an important role for reducing plagiarism in journals. In this case, if there is any code of ethics regarding a plagiarism policy, then it will help the executor or editor to provide a litigation burden against a plagiarist, and this kind of action may have an important influence on the author's or writer's attitudes regarding plagiarism $(2004,492)$.

Additionally, in another article by Sung-Tae Hong, being an editor, the writer tells her experiences related to plagiarism in the Journal of Korean Medical Science. And she states that although there are rules and awareness campaigns, plagiarism still exists and causes disregard for or ruins the trustworthiness of scholarly journals and scientific communications. She also emphasizes that with the spread of internet databases all around the world, plagiarism cases will increase, so editors will put extra effort to tackle the situation. Furthermore, she recommends editors to upgrade and be aware of the deficiencies of their plagiarism detecting software, and try to get information about external editing services from authors.

Moreover, based on the research which was conducted by Thomas and Bruin who referred that the involvement of more writers in paper work may prevent or reduce the possibility of plagiarism rather than single author work, and we all should focus on the quality of work rather than the quantity of work by avoiding the intention of having more output $(2015,2)$. They also mentioned that by using modern software technology and severe castigation of the authors, plagiarism may be detected.

On the other hand, on the plagiarism issue, other articles mainly focus on plagiarism in the academic sphere and the reasons of plagiarism. For instance, through the research of Roa and Andrade, they narrate that nowadays people are more concerned about the quantity of publishing papers rather than the quality of the papers because of limited time to publish, or maybe the academic pressure that forces them to publish more papers, and this modern technological world has made such kind of activities possible by availing adequate, plenty of sources in a website $(2014,211)$.

In the article by Zhang and JIA. Xiaoyan, they have found that the tendency of plagiarism may arise from culture, language differences or even may be from the perspective of a country's development because in the western countries plagiarism policies have been introduced long time ago when compared to developing country $(2012,305)$. In addition, the authors also stress that via the establishment of global ethical standards, the degree of plagiarism may decrease around the globe.

Contrary to this view, based on the article written by Wiwanitkit and Wiwanitkit, plagiarism can be seen anywhere, in all people, regardless of the person's status or country. It can be either due to institutional or academic pressure which can force them to publish regardless of the paper's quality or due to poor technological devices. The lack of proper institutional punishment to the plagiarist can be another reason behind this academic crime $(2017,310)$.

Lastly, a research was conducted by Bazdaric, in which he stated that many countries in the world do not speak English as a first language so, the language barrier when writing an article can be considered as one of the basic and unsearchable reasons behind plagiarism $(2012,2)$. Ethics also plays an essential role in our daily academic life, therefore removing ethical and moral education systems from our academic syllabus may lead us to have the intention to commit the crime of plagiarism during our academic career. As an example, the author mentioned Croatia. 


\section{Methodology}

The research will be done based on secondary data, and the data will be collected through magazines, journals, articles and internet materials. We will be looking into different journals from both Turkey and outside of Turkey, in order to find out their policies regarding plagiarism. The journals we will look at are mostly social sciences journals and some other journals on engineering and technology. We will also look at informative articles and studies about plagiarism. We will try to investigate the similarities and differences from the perspective of their policies. We will look at how the journals attach importance to the subject of plagiarism, whether they have implemented their policies, whether there is any work that has been revealed and punished, and how this whole process is handled. After all, we will combine all of them and will make a perfect plagiarism policy to prevent plagiarism for future generations.

We will conduct a review based on a draft of 37 journals, which will be composed of 17 Turkish and 20 foreign journals, and we will submit a compiled study according to this draft's results. In our draft, there will be five determinants, which consist of existence, accessibility, guidelines, details and penalties, to evaluate all the journals and to reach a general conclusion. By creating such a draft, we will understand how much the journals and countries give importance to the subject of plagiarism. First of all, we will look at if there is a plagiarism policy in the journals in the existence stage. In the phase of accessibility, we will investigate whether it is easy to reach this information or whether it requires some effort to find. In the third stage, which is guidelines, we will see if there is any guidance in the journal about publishing articles and obeying the rules of plagiarism that makes it easy to understand for authors. The fourth stage, which is details, includes understanding whether plagiarism policies and rules in the journals are detailed or not. In the last stage, which is penalties, we will look at whether journals have penalties that are implemented if the authors do not obey the plagiarism policies.

\section{Plagiarism Policies in Journals}

Plagiarism policies of Turkish academic journals generally take place at under the heading called "publication terms", and the majority of them are published under DergiPark (JournalPark). In the website of JournalPark, it is emphasized that the system has aims to "improve the quality and aid in the development of academic publishing in Turkey, in accordance with international standards, enhance the visibility and usage of national academic journals worldwide, and ensure the implementation of the ULAKBİM Journal Management System efficiently" (https://dergipark.org.tr/page/about). However, only "Peer-reviewed academic journals published in Turkey can participate in JournalPark by filling out the Application Form in JournalPark website" (https://dergipark.org.tr/page/about). The service has 2300 journals and it is important that it is not an indexing system. It only leads academic journals to reach international standards of academic publishing. In terms of plagiarism or copyright issue, JournalPark does not take any responsibility. All responsibility belongs to journal owners and authors.

Since the majority of Turkish journals take place under JournalPark, a sample of academic journals was taken to examine their plagiarism policies. During this process, it was observed that publication terms parts of Turkish journals resemble each other. But in terms of having detailed context in the publication terms part, scientific journals have more detail than social sciences. Most importantly, their plagiarism policy is published under the publication terms heading and most of them mainly include some conditions related to plagiarism and an explanation of the submission and evaluation process. They do not include any charges in the case of plagiarism. All documents received are checked with "Plagiarism Detection Software Programs" (Ithenticate, Turnitin) for plagiarism, prior to the review process.

Starting with social sciences journals, for example, in the website of journal celled International Journal of Islamic Economics and Finance Studies (IJISEF), the plagiarism policy is shown in different tab, and it only includes some conditions. The first condition is that all manuscripts are screened by plagiarism detection software "iThenticate" and if the editorial team of the journal identifyies a similarity rate higher than $20 \%$, they reject the manuscript and they want author(s) to submit their text after revision. Also, if it is under $20 \%$ for similarity for single source is lower or equal to $3 \%$ will be accepted during a double blind peer review process. 
In another journal called Social Sciences Research Society Journal, under the heading of ethical codes, the journal touches the plagiarism policy. It is stated that codes which are admitted and published by Committee on Publication Ethics (COPE) are accepted. And also, all authors are expected not to have submitted and published articles sent to the Social Sciences Research Society Journal in another journal or mean. In addition, authors should give references for all attributions and guarantee that it does not have any plagiarism and that the work totally belongs to them. And before publishing, articles are uploaded to "Turnitin" and/or "iThenticate" and confirmed by an editorial board. Under this context, no charges are stated, but it is emphasized that in the case of plagiarism, the author has legal responsibilities.

As above, the Journal of Social Sciences also has a condition that article had not been published before. Under the heading called publication principles, the evaluation process is explained. Firstly, the editor and his/her assistants control the article in terms of compatibility with spelling rules and publication principles. If any correction is needed, the article is sent to the writer in this process, and after this step, the plagiarism report of the article is taken. If there is no problem in the plagiarism report, the article is submitted to the publication evaluation board including two referees. Referees are the specialists whose disciplines are related to the area that article represents. It is important that authors' names are kept confidential from the referees. After that, if the referees accept the article, it is published. If one accepts and the other does not accept, a third referee is selected. Publication decision should be taken in 30 days. As in the Social Sciences Research Society Journal, all legal responsibility related to plagiarism is left to the author, and any other charge which is implemented by the journal, or what steps should be taken in the case of plagiarism, is not explained.

As it is implied before, when the publication term parts of scientific journals are compared with the same parts of social science journals, the publication term parts of scientific journals have more details. By the way, it should also be noted that journals taking above part are well-known and some of them have international referee boards. But even if it is the case, they do not have much more detail related to publication terms and plagiarism. On the other hand, for scientific journals, the situation is different. For instance, TUBITAK has an instruction guideline for authors which was updated in 2019. In this guideline, the submission and evaluation process is explained in detail. There are 4 steps which are submission, first control, scientific evaluation and publication. In the first step the authors confirm that their "article has not been published anywhere, that they are not being considered for publication simultaneously elsewhere and that they are not going to be submit it for publication elsewhere" (TUBITAK, 2019). After that, they are sent to the first control process. In this process, scope check, preliminary language check and technical control are done. In the technical control, "iThenticate" is used and if the similarity rate is above $25 \%$ scores, papers are returned to authors. However, if similarity is above $50 \%$, the board may decide to ban the author from the journal and his/her future submissions are not published. Revise for meaning

"Peer review process is single blind; referees are kept anonymous. Manuscripts may be rejected without peer review by the editor-in-chief if they do not comply with the instructions for authors or if they are beyond the scope of the journal. After a manuscript has been accepted for publication, i.e. after referee-recommended revisions are complete, the author will not be permitted to make changes that constitute departures from the manuscript that was accepted by the editor." (TUBITAK 2019).

It is important that processes are done seriously and TUBITAK has certain rules. If plagiarism is detected, it may cause the author to be banned from the journal. Additionally, the guideline has a plagiarism subtitle. In this part, it is stated that using someone else's ideas or slightly changing them without citation is considered plagiarism and is not tolerated. Even if it has proper citation for parts which are directly taken from other writer's work but it does not have quotation marks, it is still regarded as plagiarism.

Journal of Accounting, Finance and Auditing Studies (JAFAS) uses a full double-blind refereeing process for review and publication. This process includes some steps. First, the paper is sent to 2 reviewers for review, and the reviewers determine whether the paper is accepted or rejected. If papers need some changes to be published, the same reviewers check the revision version of papers so that they can compare before and after versions of papers. If plagiarism is detected at any stage, JAFAS asks the author to rewrite the article or to make quotations and citations in a proper and complete manner. Every 
manuscript sent to JAFAS is scanned for plagiarism using the "iThenticate" software program. The journal does not accept articles that have more than $25 \%$ plagiarism. If plagiarism is extensive (more than $25 \%$ ), the article may be rejected and the author's institution/employer notified.

Adam Academy is a social science journal that started publishing in 2011, dealing with topics such as history, geography, economics, finance and international relations during the Ottoman period. Turkish, English, German, French, Arabic and Persian languages are accepted. The authors' work is expected to be original and not previously published elsewhere. If the authors have benefited from the work of others, they need to be cited or quoted in full and properly. We can say that Adam Academy attaches more importance to ethics and plagiarism than other Turkish journals because they explained this issue in detail under different headings. For example, the ethical responsibilities of the authors, the ethical responsibilities of the publishers, the ethical responsibilities of the editors, the ethical responsibilities of the arbitrators are explained in separate headings. If an ethical violation, such as plagiarism, is found in an article, 'Retracted' is added under the electronic name of the article. The reasons for the retraction of the study and, if any, detailed sources of evidence are published together. A notice of retraction is posted on the ad page of the Adam Academy's website, so everyone can see it. In addition, the retraction notices are forwarded to the institutions and organizations in which the journal is indexed and to the National Library Presidency to be recorded in directory systems and catalogs. As a result, we can say that Adam Academy has explained in detail the path to be followed, and what should be done if plagiarism and other ethical violations are detected.

International Journal of Research Culture Society (IJRCS) contains detailed information on plagiarism under different headings such as 'Plagiarism Policy', 'Publication Policy' and 'Publication Ethics' on its website. It also mentioned the penalties under the plagiarism policies. First, it gives information about what plagiarism is, what situations it covers, and what we need to do to avoid plagiarism. IJRCS also expects original works from the authors. IJRCS expects $85 \%$ originality from the authors as a prerequisite for accepting an article. If the authors benefit from the work of others, they have to make a correct and complete quotation and reference. Manuscripts with less $\% 85$ originality are directly rejected in a first editorial review of quality and originality check. All articles submitted to IJRCS are subject to plagiarism testing through software programs. In the articles presented to IJRSS, the primary way to determine plagiarism is through the Executive Editor. Complaints are first submitted to the Executive Editor. After an Executive Editor faces plagiarism, he reviews all the evidence and makes a preliminary ruling on the request. If plagiarism is detected, first of all, a formal letter of apology is required with an admission letter that accepts plagiarism from the author. If the paper is under submission, the paper can be automatically rejected by the Managing Editor or the Editor board without further revisions. If an author's article has been retracted, the journal may impose a formal embargo on the author's works for a certain period of time.

International Journal of Economics and Financial Issues (IJEFI) is an international academic journal. The purpose of the journal is to publish high quality articles in the field of economics, finance and other related subjects. Plagiarism is strictly prohibited. Papers that contain plagiarism are not permissible for publication. All the papers that are received to be publish are controlled by "iThenticate" Plagiarism Detection Program (http://www.ithenticate.com) before taking the papers into the review process. This journal has emphasized so sincerely on publication ethics and publication malpractice which can be clearly seen from their segregation of duty of author, editor and reviewers under different headline. For example, the journal authority will take acknowledgement that the work which is done by an author is original and the work is not stolen from anywhere else. The author has to affirm that his/her work has not been published or submitted before. The author's paper should contain all details and references for the purpose of replication or repetition, and if there is any error that has already been found in author's published manuscript in this case, the author has to notify the editor about this issue. There is an open access opportunity for all contents to conduct research which creates a great atmosphere among people for exchanging global knowledge, but the pity is that they have not mentioned the penalties that should be imposed on someone if she/he commits plagiarism.

International Journal of Economic Science is published since 2012 by The International Institute of Social and Economic Science (IISES) but the journal publishes semiannually since 2017. The aim of the journal is to publish those articles which 
can contribute to spread knowledge, not only theoretical and empirical but also case studies related with economic theory, finance, banking, international trade and related disciplines. The journal is freely available online. There is also an open access facility with the aim to exchange knowledge. In this case, an author has to agree with this open access policy. During the review process, articles may be rejected if articles are not related with the subject matter or are poor in term of quality. The review process takes two months. If the article is accepted, then it will be published within four months. To publish or submit an article, the author does not have to pay any fees. The journal use creative commons copy right license policy CCBy. In this case, the author makes an agreement with the journal that his/her work is allowed to be copied. During a paper submission to the journal, the author has to enunciate that this work belongs to him and is original and has neither been submitted nor published before in any other journal. After that, all the received papers are scanned by the editor to discover plagiarism. If there is any significant error found in the article, then the article must be removed from the journal and in the case of plagiarism, the complete article will be withdrawn from the journal with a note in which they refer the author's name and a description of the plagiarism. In this we can also find the segregation of duty among author, editor and reviewers, which is the best way to improve the quality and integrity of a journal, but the bitter truth is that we have not even found any penalties for committing plagiarism crime against a plagiarist. There is no clear mentioning about the percentage of plagiarism that should be considered as an acceptance or a rejection.

International Journal of Social Science and Humanity Studies: It is an open access, double blind peer reviewed, international journal. This journal is published by the Social Science Research Society. The aim of the journal is to publish high quality research studies in the area of social science, such as economics, business, management, law, political science, sociology philosophy, ethics, etc. An article accepted by this journal can be theoretical, empirical, applied, case based or policy oriented in the area of social science. No fees are taken neither for submission nor publication. It is mandatory for author to participate in the peer review process. Authors must provide the list of references in an orderly base, and have to confess if he or she receives any financial support. Authors cannot publish the same article in another journal. There is strict publication ethics against any publication malpractice. Author work has to be original. Author has to acknowledge that he/she did not hide any actual or potential conflict of interest with their work in the same way the journal also commits to a fair peer review of submission and publication work to prevent the actual or potential conflict of interest. All the papers that are received for publication are controlled by "Turnitin". Similar analysis papers are checked by the handing editor. If the editor finds any plagiarism in the similar analysis paper, then this paper will be rejected without considering further review process. Articles should be submitted online. Submission through email is not accepted. After a primary assessment by the editor, the article will go for peer review process. Reviewers are asked to evaluate the paper based on originality, methodology, ethical guideline and accurate referrences, language correction is not a part of the review process. There is no specific time to review the paper, it totally depends on the reviewers. There are no second reviewers to review the manuscript, if the editor is convinced by the reviewers. The acceptance, rejection and revision of the paper depend on the reviewers' report. After revision, the revised manuscripts are sent to the initial reviewers to check the paper again. Reviewers report and final decision of editor should be provided within ten weeks.

As we have already mentioned, it is an open accessible freely international journal via internet. That is why authors must give permission to the third party to use and reproduce the article. This journal is published under Creative Commons Attribution (CC-BY) license. This license is developed to provide open access facility so that anyone can easily and freely download, reuse, or redistribute the article, as long as original work is cited. There is some publishing agreement which is a copyright attributed to the author. The materials which are contained in the papers are not defamatory, unlawful, invasive of another person privacy, hateful, racially, ethnically objectionable, abusive, threating, harmful or in contempt in court. The author has to assure the journal that the paper presented is based on original materials and does not violate anyone's copyright. The author has to indemnify the journal against any claim as a result of copyright infringement of others. 
Table 1: Turkish Journals

\begin{tabular}{|c|c|c|c|c|c|}
\hline Journal Name & Existence & Accessibility & Guidelines & Details & Penalties \\
\hline $\begin{array}{l}\text { International Journal of Islamic Economics and Finance } \\
\text { Studies }\end{array}$ & $\checkmark$ & $\checkmark$ & $\checkmark$ & $\checkmark$ & \\
\hline Social Science Research Society Journal & $\checkmark$ & & $\checkmark$ & $\checkmark$ & \\
\hline TÜBİTAK Academic Journals & $\checkmark$ & & $\checkmark$ & $\checkmark$ & $\checkmark$ \\
\hline Istanbul Journal of Economics & $\checkmark$ & & $\checkmark$ & & \\
\hline Bulletin of Economic Theory and Analysis (2016) & $\checkmark$ & & $\checkmark$ & & \\
\hline International Review of Management and Marketing (2011) & $\checkmark$ & & $\checkmark$ & & \\
\hline The Journal of Academic Social Science Studies (2019) & $\checkmark$ & $\checkmark$ & $\checkmark$ & $\checkmark$ & \\
\hline Journal of Educational Sciences Research (2019) & $\checkmark$ & $\checkmark$ & $\checkmark$ & & \\
\hline Journal of Life Economics (2014) & $\checkmark$ & & $\checkmark$ & $\checkmark$ & \\
\hline Business and Economics Research Journal (2018) & $\checkmark$ & & $\checkmark$ & & \\
\hline Middle East Journal of Science (2014) & $\checkmark$ & $\checkmark$ & $\checkmark$ & & \\
\hline $\begin{array}{l}\text { International Journal of Enterpreneurship\& Management } \\
\text { Inquiries (2017) }\end{array}$ & $\checkmark$ & $\checkmark$ & $\checkmark$ & & \\
\hline Journal of Research in Economics, Politics \& Finance (2016) & $\checkmark$ & $\checkmark$ & $\checkmark$ & & \\
\hline The Journal of International Relations (2004) & $\checkmark$ & $\checkmark$ & $\checkmark$ & & \\
\hline Journal of Anatolian Education Research (2017) & $\checkmark$ & $\checkmark$ & $\checkmark$ & $\checkmark$ & \\
\hline Journal of American Studies of Turkey (1995) & $\checkmark$ & & $\checkmark$ & & \\
\hline Adam Academy (2011) & $\checkmark$ & $\checkmark$ & $\checkmark$ & $\checkmark$ & $\checkmark$ \\
\hline
\end{tabular}

\begin{tabular}{|c|c|c|c|c|c|}
\hline Journal Name & Existence & Accessibility & Guidelines & Details & Penalties \\
\hline Journal of Economics and Financial Issues & $\checkmark$ & & $\checkmark$ & & \\
\hline International Journal of Economic Science & $\checkmark$ & & $\checkmark$ & & $\checkmark$ \\
\hline Journal of Finance and Economics & $\checkmark$ & $\checkmark$ & $\checkmark$ & $\checkmark$ & $\checkmark$ \\
\hline International Journal of Research Culture Society & $\checkmark$ & $\checkmark$ & $\checkmark$ & $\checkmark$ & $\checkmark$ \\
\hline Journal of Accounting, Finance and Auditing Studies & $\checkmark$ & & $\checkmark$ & $\checkmark$ & \\
\hline Journal of Accounting and Taxation & $\checkmark$ & $\checkmark$ & $\checkmark$ & $\checkmark$ & \\
\hline Journal of Finance and Accounting & & & $\checkmark$ & $\checkmark$ & \\
\hline International Journal of Business and Management & $\checkmark$ & & $\checkmark$ & & $\checkmark$ \\
\hline Journal of Health and Social Sciences & $\checkmark$ & & $\checkmark$ & $\checkmark$ & $\checkmark$ \\
\hline The Journal of Asian Finance, Economics and Business & $\checkmark$ & $\checkmark$ & $\checkmark$ & $\checkmark$ & \\
\hline Balkan Medical Journal & $\checkmark$ & & $\checkmark$ & $\checkmark$ & \\
\hline Journal of Engineering & $\checkmark$ & & $\checkmark$ & & $\checkmark$ \\
\hline Universal Journal of Engineering Science & $\checkmark$ & $\checkmark$ & $\checkmark$ & $\checkmark$ & $\checkmark$ \\
\hline The Open Access Journal of Science and Technology & $\checkmark$ & $\checkmark$ & $\checkmark$ & $\checkmark$ & $\checkmark$ \\
\hline Journal of International Finance Studies & $\checkmark$ & $\checkmark$ & $\checkmark$ & $\checkmark$ & $\checkmark$ \\
\hline Journal of Medical Sciences & $\checkmark$ & & $\checkmark$ & $\checkmark$ & $\checkmark$ \\
\hline $\begin{array}{l}\text { AIMS Medical } \\
\text { Science }\end{array}$ & $\checkmark$ & $\checkmark$ & $\checkmark$ & & \\
\hline The American Institute of Aeronautics and Astronautics & $\checkmark$ & $\checkmark$ & $\checkmark$ & $\checkmark$ & $\checkmark$ \\
\hline The Energy Journal & $\checkmark$ & $\checkmark$ & $\checkmark$ & & \\
\hline International Journal of Recent Technology and Engineering & $\checkmark$ & $\checkmark$ & $\checkmark$ & $\checkmark$ & $\checkmark$ \\
\hline
\end{tabular}


Based on the framework, we have come to the conclusion that every journal has a policy and it exists. In the same way, all the journals have provided guidelines for authors, reviewers and editors but the number of journals. Looking at the results of the draft, it can be concluded that the biggest difference between Turkish and foreign journals is whether the plagiarism policies are detailed and whether they contain punishment. Journals provide information about accessibility and details are bit less than we expected. which are $\% 54$ for easy accessibility and $\% 56$ for details information in terms of ratio. It is remarkably astonishing that the number of journals which include penalties in their policy is very little. In terms of ratio, it is only $37 \%$ journal.

It can be argued that foreign journals on penalties are more deterrent because there is little information about sanctions and fines in Turkish journals. In addition, Turkish journals usually contain simple and basic information about plagiarism. If Turkish journals contained more detailed and explanatory information about plagiarism, the authors and academics would be more careful.

\section{Conclusion}

Plagiarism has become an important and more well-known subject especially in recent years. In many countries, especially in master's and doctoral theses, plagiarism offenses are very common. While writing articles, many authors and academics commit plagiarism but it is not recognizable, as much as students' plagiarism. Therefore, this paper tries to find the plagiarism crimes of authors and academicians by examining the publication, ethics and plagiarism policies of the journals. We investigated how much importance the journals give to this issue, and whether there are previously retracted articles or any other penalties were given to the plagiarist. As a result of our research, we have seen such events, but we could not find clear and precise information. We could not find the names of the authors and academicians who plagiarized in any source, the work they plagiarized or the penalties they received.

It is very unfortunate to share that the number of journals which provide both easy accessibility and penalties is very little, but it is clearly mentioned in almost all the journals, that their main purpose is to publish high quality articles and to contribute to spreading knowledge We are very surprised to see the number of journals that include penalties. It is human nature to commit crimes if there are no penalties. In this regard, it is very important for every journal to include penalties in their policies, otherwise people will not take the plagiarism issue as serious as it is supposed to be taken. According to our opinion, the lack of proper penalties is the main source of plagiarism. And finally, this paper provides adetailed analysis about information which is provided by journals about themselves. The number of journals which provide detailed information about themselves is not satisfying. In this matter, we will suggest to all journals that they should provide detailed information regarding their own journal. Otherwise it will be very hard for authors to prepare a paper based on their rules and regulations.

Grant Support: The authors received no financial support for this work.

\section{References}

JournalPark. Retrieved from https://dergipark.org.tr/page/about

International Journal of Islamic Economics and Finance Studies Plagiarism Policy. Retrieved from https://dergipark.org.tr/ijisef/ page $/ 3858$

Social Sciences Research Society Journal Author Guidelines. Retrieved from http://dergipark.ulakbim.gov.tr/nwsasocial/about/ submissions\#copyrightNotice

TÜBİTAK Academic Journals Instruction for Authors. Retrieved from http://journals.tubitak.gov.tr/medical/i2csag.pdf

Karabag, S. F., and Berggren, C. (2012). Retraction, dishonesty and plagiarism: Analysis of a crucial issue for academic publishing, and the inadequate responses from leading journals in economics and management disciplines. Journal of Applied Economics and Business Research, 2(3), 172-183. 
Laskar, M. (2017). Publishing articles in scientific journals: a concern for research misconduct or dishonesty (fabrication, falsification and plagiarism). Mediscope, 4(2), 1-4.

Hong, S. T. (2017). Plagiarism continues to affect scholarly journals. Journal of Korean medical science, 32(2), 183-185.

Thomas, A., and De Bruin, G. P. (2015). Plagiarism in South African management journals. South African Journal of Science, 111(1/2). (n.d.). Retrieved from http://www.sobiad.org/eJOURNALS/journal_IJSS/index.html

International Journal of Economics and Financial Issues. (n.d.). Retrieved from https://www.econjournals.com/index.php/ijefi/about/ editorialPolicies\#custom-1

S.r.o., I. S. (n.d.). International Journal of Economic Sciences. Retrieved from https://www.iises.net/publication-ethics-publicationmalpractice-statement.html

PLAGIARISM POLICY. (n.d.). Retrieved from https://ijrcs.org/plagiarism-policy/

International Journal of Business, Accounting and Management. (n.d.). Retrieved from http://www.doarj.org/ijbam/ open-access-policy-and-ethics/

Admin. (n.d.). About Us. Retrieved from https://jafas.org/about-this-journal/

(n.d.). Retrieved from http://dergipark.gov.tr/mufider/page/5352

ADAM AKADEMİ. (n.d.). Retrieved from http://www.adamakademi.com/site/content/yayin_ilkeleri

Shashok, K. (2011). Authors, editors, and the signs, symptoms and causes of plagiarism. Saudi Journal of Anaesthesia, 5(3), 303. doi:10.4103/1658-354x.84107

Uçak, N. Ö, \& Birinci, H. G. (2008). Scientific Ethics and Plagiarism. 187-204.

Toprak, Z. (2017). Academic Writing in Turkey: Plagiarism and Originality. Boğaziçi University Education Journal, $34(2), 1-12$.

Pennycook, A. (1996). Borrowing Others Words: Text, Ownership, Memory, and Plagiarism. TESOL Quarterly, $30(2), 201$. doi:10.2307/3588141

Grossberg, M. (2017). Plagiarism and Professional Ethics-A Journal Editors View. Academic Ethics,509-516. doi:10.4324/9781315263465-40

Bozdaric.K.(2012). Plagiarism detection- Quality management tool for all scientific journals. Croatian Medical Journal. 53(1), Page 2. Doi: $10.3325 / \mathrm{cmj} .2012 .53 .1$

Roa, T.S. S and Andrade, C. (2014). Policy of the Indian journal of psychiatry on the problem of plagiarism. Indian journal of plagiarism. 53(3), Page.211, Doi: 10.4103/0019-5545.140613.

Enders.W and Hoover.G.A. (2004). Whose line is this? Plagiarism in economics. Journal of economic literature. $42(2)$, Page, 492. Doi:10.1257/0022051041409066.

Zhang.Y.Hand JIA. Xiaoyan.(2012).A survey on the use of Cross Check for detecting plagiarism in journal article. Learning publishing. 25(4). Page. 305, Doi: 10.1087/20120408.

Wiwanitkit.S.Wiwanitkit.V.(2017). Response of author accused of plagiarism by journal auditors. Science and engineering ethics.23(1). Page.310. Doi:10.1007/s11948-016-9752-7. 